\section{Influence of seasonality on the presence of okadaic acid associated with Dinophysis species: A four-year study in Sardinia (Italy)}

\author{
Alessandro G. Mudadu, ${ }^{1}$ Anna Maria \\ Bazzoni, ${ }^{2}$ Riccardo Bazzardi, ${ }^{1}$ \\ Giuseppa Lorenzoni, ${ }^{1}$ Barbara Soro, ${ }^{1}$ \\ Nadia Bardino, ${ }^{1}$ Igor Arras, ${ }^{1}$ \\ Giovanna Sanna, ${ }^{1}$ Bruna Vodret, ${ }^{1}$ \\ Sebastiano Virgilio ${ }^{1}$ \\ ${ }^{1}$ Veterinary Public Health Institute of \\ Sardinia, Sassari; ${ }^{2}$ Regional \\ Environmental Protection Agency of \\ Sardinia, Sassari, Italy
}

\begin{abstract}
In Sardinia (Italy), bivalve molluscs production plays an important role in the trade balance. Diarrhoetic shellfish poisoning (DSP), an intoxication caused by the ingestion of bivalve molluses that have accumulated high levels of Okadaic acid (OA), may represent a serious risk for the public health and a remarkable economic loss for the producers. Aim of this work was to improve knowledge about the repeatability of OA accumulation phenomena in various seasons trying to understand whether or not there was a trend. Also, the interaction between toxic algae and OA accumulation was examined. In this study, data of lipophilic toxins, water temperature and abundance of DSP-producing microalgal species were collected in a four-year period (2015-2018) in coastal production areas of Sardinia. Several episodes of OA positive values (>160 eq $\mu \mathrm{gAO} / \mathrm{Kg}$ pe, Reg 853/04) were recorded during the study period in different production areas of Sardinia and in different seasons. A seasonal repeatability of OA accumulation in molluses was observed in some production areas; moreover, different temporal gaps between the presence of toxic algae and OA accumulation were reported. Toxicity was observed almost exclusively in Mytilus galloprovincialis Lamark (99\%), being this matrix the most abundant species bred in Sardinia.
\end{abstract}

\section{Introduction}

Phytoplankton plays a critical role in the marine ecosystem, being primary producers. It collects light energy from the sun and transforms it into chemical energy, making it available for higher trophic levels
(Chavez et al., 2011). The abundance of phytoplankton may increase during its natural seasonal cycle originating algal blooms. They can have a negative impact on marine ecosystems and the resources they provide, including fish kill, economic loss and human diseases (Hallengraeff, 2003; Anderson et al., 2012).

Harmful algal blooms (HABs) have been increasing in geographical distribution (Hallengraeff, 1993; Allen et al., 2006). This trend has been associated with several factors, including introduction of new species with ballast waters, eutrophication of coastal areas, and climate changes (Anderson et al., 2002; Edwards et al., 2006; Hegaret et al., 2008; Haisler et al., 2008; Moore et al., 2008), that include warming of the surface water temperature, reduction in $\mathrm{pH}$ due to ocean acidification, increased stratification, alteration of salinity, light field intensity, nutrient flux, and grazing (Fu et al., 2012; Wells et al., 2015). From the presence of potentially toxic harmful algal species (HAS) it is possible to have an accumulation of marine toxins in shellfish, for which toxic and non toxic algae represent the primary source of food. Potential consequent human poisoning caused by consumption of shellfish contaminated with phycotoxins have been reported for decades. Among the algal species potentially producing toxins with range expansion, some are responsible of diarrhoetic shellfish poisoning (DSP), a alimentary intoxication caused by the consumption of shellfish contaminated with diarrhoeic shellfish toxins (DTXs), produced by several species belonging to the phytoplanktonic genus Dinophysis and some benthic Prorocentrum (Yasumoto et al., 1980; Lee et al., 1989; Boni et al, 1993). The first DSP events were described in Japan in 1970s (Yasumoto et al., 1978). Since then, outbreaks of DSP were reported globally several times. The main DTXs are a group of lipophilic polyester toxins based on Okadaic acid (OA) (Aune et al., 2012), with several analogues, including dinophysitoxin-1 (DTX1), and dinophysitoxin-2 (DTX2) (Bauder et al., 1996). These toxins are inhibitor of serine/threonine protein phosphatases and cause gastrointestinal symptoms in human. Ten species of Dinophysis are able to synthesize DTXs (Roguera et al., 2014). Among these, Dinophysis acuminata Claparède \& Lachmann is the most cosmopolitan species (Pitcher and Calder, 2000; France and Mozetic, 2006). Dinoflagellates producing OA toxin group are carefully monitored in the Mediterranean basin. They may be present during different periods of the year (Naustvoll et al., 2013), or all over the year
Correspondence: Alessandro Graziano Mudadu, Veterinary Public Health Institute of Sardinia, Via Duca degli Abruzzi 8, 07100 Sassari, Italy

Cell: +39.3494141925

E-mail: alessandro.mudadu@izs-sardegna.it

Key words: Dinophysis species, Okadaic acid, Seasonality, Diarrhoetic shellfish poisoning, Mollusc production areas.

Contributions: The authors contributed equally.

Conflict of interest: The authors declare no potential conflict of interests.

Funding: None.

Received for publication: 30 September 2020 Revision received: 22 November 2020.

Accepted for publication: 3 December 2020.

This work is licensed under a Creative Commons Attribution-NonCommercial 4.0 International License (CC BY-NC 4.0).

(C) Copyright: the Author(s), 2021

Licensee PAGEPress, Italy

Italian Journal of Food Safety 2021; 10:8947

doi:10.4081/ijfs.2021.8947

(Tibiriçá et al., 2015). They can cause the accumulation of OA group toxins in bivalve molluscs when they are the only or the most abundant source of food in a certain area. OA accumulation may follow different seasonal trends depending on causative toxic algae, as well as on the climate zone of sampling location. So, DSP toxicity events are difficult to predict (Ninčević-Gladan et al., 2008).

In several studies a weak relationship between cell abundance of Dinophysis spp. and toxin levels has been found (Alvez-de Souza et al., 2014). Many factors may explain the difficulty to relate cell abundances and toxicity, e.g. water column stratification (due to interaction between wind and water temperatures) and high variability of the intracellular toxins of Dinophysis spp. during blooms (Pizzarro et al., 2009; Roguera et al., 2012; 2014). Filtration rates, accumulation of toxins and availability of alternative food sources for shellfish are factors that may determine the toxic content in bivalves too (Alves-de-Souza et al., 2014), and complicate the prediction of the toxic events based only on cell abundances. Although species of Dinophysis form a small fraction of the phytoplankton, they represent a serious threat for the ecosystem and for the human being, due to the production of toxins causing toxic episodes at a very low cell densities (Basti et al., 2015). 
The high toxicity of Dinophysis spp. at low concentrations is likely attributable to the lipophilic rather than the hydrophilic nature of the toxins (Yasumoto et al., 1978).

The aim of this work was to describe the seasonal variability of lipophilic toxins content in molluscs bred in different production areas of Sardinia (Italy). The presence of toxic algae, such as Dinophysis spp. and Prorocentrum spp., and the accumulation of lipophilic toxins over the legal limits were studied over a four-year period (2015 - 2018). Investigation of a relationship between OA accumulation and season (seasonality), is extremely important, because it may help all the expert involved in mollusc culture (producers, biologists, sanitary controllers) to plan sampling and controls in order to perform a better analysis of the risk of OA accumulation associated to each producing area.

\section{Materials and Methods}

\section{Study area}

Sardinia is an island located in the middle of the western Mediterranean Sea, with a surface of $24.090 \mathrm{~km}^{2}$ and $1849 \mathrm{~km}$ of coasts. Bivalve production and aquaculture play an important role in the economic and social systems. Shellfish farms are located along a surface area of about 1300 ha, both in marine and transitional waters, several of which subject to different human activities such as leisure or industrial activities. Different lagoons have a high trophic status (Padedda et al., 2012) with seasonal variations in nutrient concentration.

\section{Sample collection}

Water and mollusc samples were collected from a total of 18 coastal sites (Figure 1) for four years (2015-2018), by the sanitary operators of the Italian National Health System, following protocols of the Sardinian Regional Monitoring Programme, in force since 1992 and periodically updated. For every production area, one to five stations were sampled. Presence of DSTs were determinate from molluscs, whereas the presence and abundance of DSP-producing microalgal species were established in water sampling. Data about water temperature were provided when OA were higher than legal limits.

\section{Sample analysis}

Water analysis for the evaluation of the presence and abundance of HAS were performed using Utermöhl's method (1958), in accordance with the EU reference method UNI EN ISO 15204:2006. For the cell count, settling chambers under an inverted microscope were used (Olympus IX 73). HAS were identified at the species level according to IOC Taxonomic Reference List of Toxic Plankton Algae (http://www.marinespecies.org/hab/).

\section{DSP toxin analysis}

Shellfish samples collected were analysed to identify Okadaic acid (OA), Dinophysis toxins (DTXs), Pectenotoxin group (PTXs), Yessotoxins (YTXs) and Azaspiracid (AZAs) by liquid chromatography coupled with tandem mass spectrometry (LC-MS/MS) (Thermo Scientific TSQ Vantage in 2015 and AB SCIEX QTRAP 4500 from 2016 to 2018) in agreement with the official protocol (AESAN, Vigo, version 5, 2015) governed by the EC Regulation $15 / 2011$. The different phases of extraction and analysis with LC-MS/ MS are reported specifically in Bazzoni et al. (2018).

\section{Results}

From 2015 to 2018, a total of 4395 water samples ( 1715 in 2015, 1040 in 2016, 831 in 2017 and 809 in 2018) and 4732 bivalve molluscs samples (1365 in 2015, 1333 in 2016, 1125 in 2017 and 909 in 2018) were analysed. Non-compliant samples were 61, distributed as follow: 23 in 2015 ( $2 \%$ of total amount of analysed samples), 24 in $2016(2 \%), 4$ in $2017(0.4 \%)$ and 10 in $2018(1.1 \%)$ (Table 1). All of them were positive only for OA accumulation over the legal limit (160 eq $\mu \mathrm{g} \mathrm{AO} / \mathrm{Kg}$ e.p.). Positive samples were found in Tortolì (TOR) every considered year, always between February to April (17 times), and always in mussels. The maximum concentration of OA was $1092 \mu \mathrm{g}$ OA eq/kg e.p. in February 2015. Every OA positive value in

$$
\text { (a) }
$$

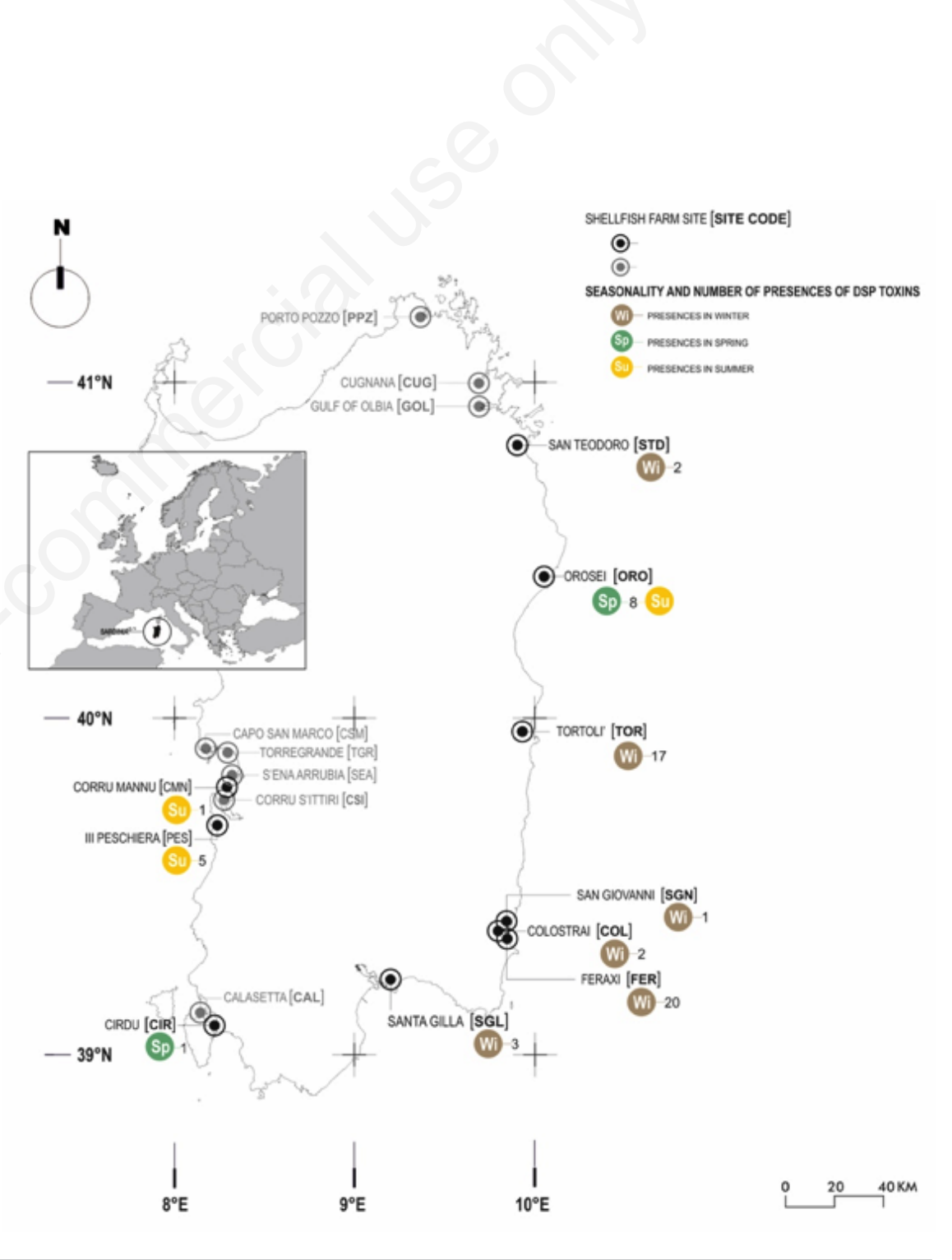

Figure 1. Spatial and seasonal distribution of $O A$ events in different shellfish farming sites from 2015 to 2018. 
mussels was observed with the only presence of $D$. acuminata, or less frequently with the contemporary presence of $D$. acuminata and D. sacculus. Rarely were detected $D$. rotundata Claparède \& Lachmann and Prorocentrum mexicanum Osorio Tafall. Unfortunately, in some occasions, no data about the previous or contemporary presence of algae were available. In Orosei (ORO), OA positive values were recorded in 2015, 2016 and 2018 in spring and summer (Table 1). Most times in which OA was higher than the legal limit $D$. acuminata was detected. Twice no algae were detected. In Feraxi (FER) all OA positive values were detected in winter, between 2015 and 2017, with a peak of $1269 \mu \mathrm{g}$ OA eq/kg e.p. in February 2015. In 2015 most times there was not a contemporary presence of toxic algae and DSP, while in 2016 they were detected together. In few cases no data were available. In San Teodoro (STD), two positive events were detected in January 2016, one with the contemporary presence of $D$. acuminata and one without. Interestingly, the positive events were detected in oysters.

In Santa Gilla (SGL), there were positive values of OA only in winter 2015; in that occasion no algae were detected. In Cirdu (CIR) there was only a single positive case, in May 2016 in mussels. In that occasion there were no algae. In III Peschiera (PES), there was only one positivity, it was the longest positive period for OA recorded in our study, from June to July 2018. On that occasion, D. acuminata and D. sacculus were observed only in June at the onset of positivity, but the presence of toxins in mussels was detected beyond the legal limits until the end of July. Corru Mannu (COR), was the only place in the west coast where the only one positive value, in summer (2018), due to a compresence of $P$. mexicanum (400 cell/1) and D. acuminata (900 cell/1).

On a total of 61 OA positive cases, in 29 events $(47.5 \%)$ we did not detect any algae, in 21 occasions $(34.4 \%)$ there were algae and $\mathrm{OA}$ at the same time and in 11 occasions $(18 \%)$ the presence of toxic algae was detected previously than OA accumulation over the legal limits.

Further details about the presence of OA above the legal limits, the presence of toxic algae and their species are given in Table 1. Data about water temperature are included.

\section{Discussion}

This study, including four years of data collected along all Sardinian mollusc production sites, documented the presence of $\mathrm{OA}$ in bivalve molluscs and that of potentially toxic microalgae belonging to Dinophysis and Prorocentrum genus, involved in the onset of DSP syndrome. Furthermore, the seasonal variability of OA content in mussels and the interaction between toxic algae and OA presence were investigated. Several cases of OA accumulation over legal limits were recorded, distributed during the four years. In winter, all of them were detected in the Sardinian east coast. Most positive cases in spring and in summer were detected on the south-west and west coasts, except for one case in east coast. No positive value was detected during autumn.

On 18 production areas analysed, 10 were characterised at least by one positive event occurred during the study period. Only in TOR, there were positive events every year, always in winter, with a variety of Dinophysis species, and in few occasions P. mexicanum. In FER there were positive events in three out of four years, in winter too, with the presence of D. acuminata and D. sacculus. Relevant is the situation recorded in ORO, where positive events were recorded for three years in spring and in summer. Every time, the algal species recorded were D. acuminata and $D$. sacculus.

In the other production areas there were positive cases only occasionally, sometimes with multiple samples in short periods when the legal limits were exceeded, but always limited to a single year. On the basis of these data, a seasonality may be supposed in ORO, FER and TOR (all located in the eastern Sardinian coast) while the other sites showed no seasonal trend. Water temperature values registered every year were almost the same in each site (Table 1), but it is difficult to understand their role of for the

Table 1. Okadaic acid (OA) positivity in bivalve molluscs related to environmental parameter and potentially toxic algae (HAS) in the various seasons from 2015 to 2018.

\begin{tabular}{|c|c|c|c|c|c|c|c|c|}
\hline Producing area & $\begin{array}{l}\text { Site } \\
\text { code }\end{array}$ & Year & $\begin{array}{l}\text { OA } \\
\text { positivities }\end{array}$ & $\begin{array}{l}\text { Total samples } \\
\text { analyzed }\end{array}$ & $\begin{array}{l}\text { Positivity } \\
\text { period }\end{array}$ & HAS species & $\begin{array}{l}\text { Temperature } \\
\left({ }^{\circ} \mathrm{c}\right)\end{array}$ & $\begin{array}{l}\text { Shellish } \\
\text { product }\end{array}$ \\
\hline Cirdu & CIR & 2016 & 1 & 65 & May & No data & 20 & Mussels \\
\hline Colostrai & COL & 2015 & 2 & 12 & February - March & No data & $12-14.2$ & Mussels \\
\hline Corru Mannu & CMN & 2018 & 1 & 94 & August & D. acuminata/P. mexicanum & 24 & Mussels \\
\hline Feraxi & FER & 2015 & 8 & 57 & February - March & D. acuminata & $10-14$ & Mussels \\
\hline Feraxi & FER & 2016 & 10 & 57 & January - March & D. acuminata/D. sacculus & $11-14.5$ & Mussels \\
\hline Feraxi & FER & 2017 & 2 & 37 & February-March & D. acuminata/D. sacculus & 13 & Mussels \\
\hline Orosei & ORO & 2015 & 2 & 26 & April & D. acuminata & 21 & Mussels \\
\hline Orosei & ORO & 2016 & 5 & 26 & June - July & D. acuminata/D. sacculus & $22-28$ & Mussels - Clams \\
\hline Orosei & ORO & 2018 & 1 & 33 & May & D. acuminata & 18 & Clams \\
\hline San Giovanni & SNG & 2015 & 1 & 46 & February & No data & 13 & Mussels \\
\hline Santa Gilla & SGL & 2015 & 3 & 91 & February & No data & $10-13.3$ & Mussels \\
\hline San Teodoro & STD & 2016 & 2 & 65 & January & D. acuminata & 14.5 & Oysters \\
\hline Tortolì & TOR & 2015 & 7 & 256 & February-March & $\begin{array}{l}\text { D. acuminata/D. sacculus } \\
\text { D. rotundata/P. mexicanum }\end{array}$ & $8.7-17.2$ & Mussels \\
\hline Tortolì & TOR & 2016 & 6 & 256 & March & D. acuminata & $11.9-12.6$ & Mussels \\
\hline Tortolì & TOR & 2017 & 2 & 202 & February & D. acuminata & 12.8 & Mussels \\
\hline Tortolì & TOR & 2018 & 2 & 186 & February & D. acuminata/D. sacculus & $11-11.2$ & Mussels \\
\hline$\underline{\text { Terza Peschiera }}$ & PES & 2018 & 5 & 25 & June - July & D. acuminata/D. sacculus & $23-26$ & Mussels \\
\hline
\end{tabular}


Table 2. Toxic algal abundances and temporal gaps between the presence of toxic algae (Harmful algal species-Diarrhoetic shellfish poisoning, HAS-DSP) and OA accumulation.

\begin{tabular}{|c|c|c|c|c|c|c|c|}
\hline $\begin{array}{l}\text { Sampling } \\
\text { station }\end{array}$ & $\begin{array}{l}\text { Positive test } \\
\text { data }\end{array}$ & $\begin{array}{c}\text { OA values } \\
\text { (ugao Eq/Kg E.P.) }\end{array}$ & $\begin{array}{l}\text { HAS sampling } \\
\text { data }\end{array}$ & HAS present & $\begin{array}{l}\text { HAS abundance } \\
\text { (Cells/L) }\end{array}$ & $\begin{array}{l}\text { Temporal gap } \\
\text { HAS-DSP }\end{array}$ & Water temperature \\
\hline Feraxi 1 & 03/02/2015 & 1269 & 13/01/2015 & Dinophysis acuminata & $<120$ & 3 weeks earlier & $10^{\circ} \mathrm{C}$ \\
\hline Feraxi 1 & 10/02/2015 & 263.1 & 10/02/2015 & None & $<120$ & & $12^{\circ} \mathrm{C}$ \\
\hline Feraxi 1 & 19/02/2015 & 516.2 & 19/02/2015 & None & $<120$ & & $11.5^{\circ} \mathrm{C}$ \\
\hline Feraxi 1 & 23/02/2015 & 738.9 & 23/02/2015 & None & $<120$ & & $11.5^{\circ} \mathrm{C}$ \\
\hline Feraxi 1 & 26/02/2015 & 317 & Data non available & & & & \\
\hline Feraxi 1 & 09/03/2015 & 424.5 & 04/03/2015 & Dinophysis acuminata & $<120$ & 5 days earlier & $10^{\circ} \mathrm{C}$ \\
\hline Feraxi 1 & 19/03/2015 & 383.1 & Data non available & & & & \\
\hline Feraxi 1 & 23/03/2015 & 257.2 & Data non available & & & & \\
\hline Santa Gilla 2 & 03/02/2015 & 1480 & 03/02/2015 & None & $<120$ & & $10^{\circ} \mathrm{C}$ \\
\hline Santa Gilla 2 & 19/02/2015 & 704.8 & 19/02/2015 & None & $<120$ & & $13.3^{\circ} \mathrm{C}$ \\
\hline Santa Gilla 3 & 19/02/2015 & 498.8 & 19/02/2015 & None & $<120$ & & $13.3^{\circ} \mathrm{C}$ \\
\hline San Giovanni 4 & 23/02/2015 & 618.9 & 23/02/2015 & None & $<120$ & & $13^{\circ} \mathrm{C}$ \\
\hline Colostrai & 19/02/2015 & 341.3 & 19/02/2015 & None & $<120$ & & $12^{\circ} \mathrm{C}$ \\
\hline Colostrai & 09/03/2015 & 470.4 & 09/03/2015 & None & $<120$ & & $14.2^{\circ} \mathrm{C}$ \\
\hline Orosei 1 & 27/04/2015 & 184 & 27/04/2015 & Dinophysis acuminata & 1560 & Contemporary presence & $21^{\circ} \mathrm{C}$ \\
\hline Orosei 4 & $27 / 04 / 2015$ & 205 & 27/04/2015 & Dinophysis acuminata & 1680 & Contemporary presence & $21^{\circ} \mathrm{C}$ \\
\hline Tortoli 1 & $11 / 02 / 2015$ & 192.5 & $11 / 02 / 2015$ & Dinophysis acuminata & 1800 & Contemporary presence & $8.7^{\circ} \mathrm{C}$ \\
\hline Tortoli 2 & 11/02/2015 & 1092 & 11/02/2015 & $\begin{array}{l}\text { Dinophysis acuminata } \\
\text { Dinophysis sacculus }\end{array}$ & $\begin{array}{l}142662 \\
37895\end{array}$ & Contemporary presence & $8.7^{\circ} \mathrm{C}$ \\
\hline Tortoli 3 & 26/02/2015 & 188.2 & 26/02/2015 & $\begin{array}{l}\text { Dinophysis acuminata } \\
\text { Dinophysis sacculus }\end{array}$ & $\begin{array}{c}14400 \\
400\end{array}$ & Contemporary presence & $10^{\circ} \mathrm{C}$ \\
\hline Tortoli3 & $11 / 03 / 2015$ & 301.3 & $11 / 03 / 2015$ & Dinophysis acuminata & 2400 & Contemporary presence & $11.3^{\circ} \mathrm{C}$ \\
\hline Tortoli 3 & $18 / 03 / 2015$ & 326.5 & Data non available & & & & $11.3^{\circ} \mathrm{C}$ \\
\hline Tortoli3 & $23 / 03 / 2015$ & 181.7 & Data non available & 18 & & & $12^{\circ} \mathrm{C}$ \\
\hline Tortoli 3 & $15 / 04 / 2015$ & 210.2 & $15 / 04 / 2015$ & Dinophysis acuminata & 9400 & Contemporary presence & $17.2^{\circ} \mathrm{C}$ \\
\hline Feraxi 1 & 07/01/2016 & 312 & 07/01/2016 & $\begin{array}{l}\text { Dinophysis acuminata } \\
\text { Dinophysis sacculus }\end{array}$ & $\begin{array}{l}1040 \\
120\end{array}$ & Contemporary presence & $14.5^{\circ} \mathrm{C}$ \\
\hline Feraxi 1 & 13/01/2016 & 1086 & 13/01/2016 & $\begin{array}{l}\text { Dinophysis acuminata } \\
\text { Dinophysis sacculus }\end{array}$ & $\begin{array}{l}1720 \\
<120\end{array}$ & Contemporary presence & $14.5^{\circ} \mathrm{C}$ \\
\hline Feraxi 1 & 20/01/2016 & 790 & 20/01/2016 & None & $<120$ & & $11^{\circ} \mathrm{C}$ \\
\hline Feraxi 2 & 20/01/2016 & 660 & $12 / 01 / 2016$ & Dinophysis acuminata & 120 & 8 days earlier & $11^{\circ} \mathrm{C}$ \\
\hline Feraxi 1 & 03/02/2016 & 547 & $03 / 02 / 2016$ & Dinophysis acuminata & $<120$ & Contemporary presence & $14^{\circ} \mathrm{C}$ \\
\hline Feraxi 1 & 10/02/2016 & 778 & 10/02/2016 & Dinophysis acuminata & $<120$ & Contemporary presence & $14^{\circ} \mathrm{C}$ \\
\hline Feraxi 1 & 17/02/2016 & 315 & Data non available & & & & $13^{\circ} \mathrm{C}$ \\
\hline Feraxi 1 & 19/02/2016 & 273 & Data non available & & & & $13^{\circ} \mathrm{C}$ \\
\hline Feraxi 1 & 24/02/2016 & 385 & 24/02/2016 & Dinophysis acuminata & $<120$ & Contemporary presence & $14^{\circ} \mathrm{C}$ \\
\hline Feraxi 1 & 04/03/2016 & 317 & 04/03/2016 & Dinophysis acuminata & $<120$ & Contemporary presence & $13^{\circ} \mathrm{C}$ \\
\hline San Teodoro 1 & $13 / 01 / 2016$ & $173 \pm 62$ & 13/01/2016 & Dinophysis acuminata & 120 & Contemporary presence & $14.5^{\circ} \mathrm{C}$ \\
\hline San Teodoro 2 & 13/01/2016 & $161 \pm 58$ & 13/01/2016 & None & $<120$ & & $14.5^{\circ} \mathrm{C}$ \\
\hline Tortoli 1 & 07/03/2016 & $247 \pm 89$ & 01/03/2016 & $\begin{array}{l}\text { Dinophysis acuminata } \\
\text { Dinophysis rotundata }\end{array}$ & $\begin{array}{r}2200 \\
200\end{array}$ & 6 days earlier & $12^{\circ} \mathrm{C}$ \\
\hline Tortoli 2 & 07/03/2016 & & 01/03/2016 & $\begin{array}{l}\text { Dinophysis acuminata } \\
\text { Dinophysis sacculus }\end{array}$ & $\begin{array}{l}1800 \\
200\end{array}$ & 6 days earlier & $12.4^{\circ} \mathrm{C}$ \\
\hline Tortoli 3 & 07/03/2016 & $252 \pm 91$ & 01/03/2016 & $\begin{array}{l}\text { Dinophysis acuminata } \\
\text { Dinophysis sacculus } \\
\text { Dinophysis rotundata } \\
\text { Prorocentrum mexicum }\end{array}$ & $\begin{array}{l}3800 \\
200 \\
200 \\
400\end{array}$ & 6 days earlier & $11.9^{\circ} \mathrm{C}$ \\
\hline Tortoli 1 & 09/03/2016 & $204 \pm 83$ & Data non available & & & & $12.6^{\circ} \mathrm{C}$ \\
\hline Tortoli 2 & 09/03/2016 & $299 \pm 115$ & Data non available & & & & $12.6^{\circ} \mathrm{C}$ \\
\hline Tortoli 3 & 09/03/2016 & $200 \pm 82$ & Data non available & & & & $12.4^{\circ} \mathrm{C}$ \\
\hline Cirdu & 23/05/2016 & 675 & 23/05/2016 & None & $<120$ & & $20^{\circ} \mathrm{C}$ \\
\hline
\end{tabular}


Table 2. Continued from previous page.

\begin{tabular}{|c|c|c|c|c|c|c|c|}
\hline $\begin{array}{l}\text { Sampling } \\
\text { station }\end{array}$ & $\begin{array}{l}\text { Positive test } \\
\text { data }\end{array}$ & $\begin{array}{c}\text { OA values } \\
\text { (gao Eq/Kg E.P.) }\end{array}$ & $\begin{array}{l}\text { HAS sampling } \\
\text { data }\end{array}$ & HAS present & $\begin{array}{l}\text { HAS abundance } \\
\text { (Cells/L) }\end{array}$ & $\begin{array}{l}\text { Temporal gap } \\
\text { HAS-DSP }\end{array}$ & Water temperature \\
\hline Orosei 4 & 15/06/2016 & 607 & 19/05/2016 & Dinophysis acuminata & 800 & $>3$ weeks earlier & $22^{\circ} \mathrm{C}$ \\
\hline Orosei 6 & 29/06/2016 & 1066 & 19/06/2016 & Dinophysis acuminata & 1200 & 10 days earlier & $22^{\circ} \mathrm{C}$ \\
\hline Orosei 6 & 04/07/2016 & 371 & 04/07/2016 & $\begin{array}{l}\text { Dinophysis acuminata } \\
\text { Dinophysis sacculus }\end{array}$ & $\begin{array}{r}2200 \\
400\end{array}$ & Contemporary presence & $28^{\circ} \mathrm{C}$ \\
\hline Orosei 6 & 19/07/2016 & 299 & 19/07/2016 & None & $<120$ & & $25^{\circ} \mathrm{C}$ \\
\hline Orosei 6 & 25/07/2016 & $180 \pm 75$ & 25/07/2016 & None & $<120$ & & $25^{\circ} \mathrm{C}$ \\
\hline Tortoli 1 & 27/02/2017 & $167 \pm 70$ & 27/02/2017 & Dinophysis acuminata & 1000 & Contemporary presence & $12.8^{\circ} \mathrm{C}$ \\
\hline Tortoli 2 & 27/02/2017 & $165 \pm 69$ & 27/02/2017 & Dinophysis acuminata & 800 & Contemporary presence & $12.8^{\circ} \mathrm{C}$ \\
\hline Feraxi 1 & 28/02/2017 & $204 \pm 83$ & 21/02/2017 & $\begin{array}{l}\text { Dinophysis acuminata } \\
\text { Dinophysis sacculus }\end{array}$ & $\begin{array}{l}1000 \\
400\end{array}$ & 7 days earlier & \\
\hline Feraxi 1 & 09/03/2017 & $180 \pm 75$ & Data non available & & & & $13^{\circ} \mathrm{C}$ \\
\hline Tortoli 2 & 05/02/2018 & 174 & 05/02/2018 & Dinophysis acuminata & 500 & Contemporary presence & $11.2^{\circ} \mathrm{C}$ \\
\hline Tortoli 3 & 05/02/2018 & 161 & 05/02/2018 & Dinophysis sacculus & 100 & Contemporary presence & $11^{\circ} \mathrm{C}$ \\
\hline Orosei 4 & $16 / 05 / 2018$ & 404 & 07/05/2018 & Dinophysis acuminata & 800 & 9 days earlier & $18^{\circ} \mathrm{C}$ \\
\hline III Peschiera 1 & 07/06/2018 & 547 & 07/06/2018 & $\begin{array}{l}\text { Dinophysis acuminata } \\
\text { Dinophysis sacculus }\end{array}$ & $\begin{array}{l}18320 \\
2720\end{array}$ & & \\
\hline III Peschiera 1 & $12 / 06 / 2018$ & 405 & Data non available & & & & $25^{\circ} \mathrm{C}$ \\
\hline III Peschiera 1 & 19/06/2018 & 377 & Data non available & & & & $25^{\circ} \mathrm{C}$ \\
\hline III Peschiera 1 & 25/06/2018 & 399 & Data non available & & & & $24^{\circ} \mathrm{C}$ \\
\hline III Peschiera 1 & 28/06/2018 & 216 & Data non available & & & & $26^{\circ} \mathrm{C}$ \\
\hline III Peschiera 1 & 02/07/2018 & 270 & Data non available & 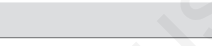 & & & $26^{\circ} \mathrm{C}$ \\
\hline Corru Mannu 2 & 28/08/2018 & 178 & 23/08/2018 & Dinophysis acuminata & 900 & 5 days earlier & $24^{\circ} \mathrm{C}$ \\
\hline
\end{tabular}

seasonality, since data of water temperature all over the years, where OA didn't exceeded legal limits, were not available to make a comparison. In the same coast, there were other sites where seasonality was not detected (among them, there were places where only a positive case was detected). Therefore, seasonality may not be related to particular features of the eastern coast, or if it may be related, is not the only factor that determine it. Toxicity was observed almost exclusively in Mytilus galloprovincialis Lamark (99\%), being this matrix the most abundant species bred in Sardinia. The HAS analysis reported that $D$. acuminata was present in most of the cases in which OA exceed legal limits and data about algal presence were available. No evident differences were detected in algal presence from one year to another where there was seasonality, neither related to the different months when OA acid positive events occurred.

Another aspect analysed in this paper was the relationship between the presence of toxic algae and the accumulation of $\mathrm{OA}$ in bivalve molluscs. Specifically, most of OA positive cases were preceded by the presence of HAS. Sometimes the elapsed period of time between the appearance of HAS and the accumulation of OA in bivalve molluscs beyond the limit allowed by law

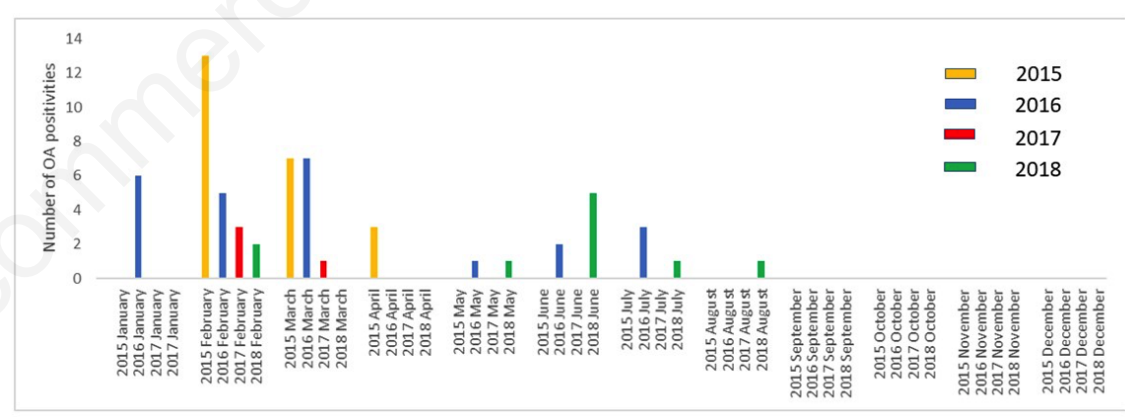

Figure 2. Monthly distribution of OA positivity events between 2015 to 2018 .

was high (Table 2). We noticed this temporal gap in $18 \%$ of positive cases. In two occasion, in FER in winter 2015 and in ORO in spring 2016, the gap was remarkable, more than three weeks between the detection of $D$. acuminata and the accumulation of OA in mussels. The other temporal gaps were on average of six days. Moreover, data showed that cell abundances of HAS is not related to the amount of OA in molluscs. Another interesting aspect is that there was not a relationship between the HAS abundances and the temporal gap between algal presence and OA accumulation over the legal limits (Table 2). This discrepancy may be associated with the spatial distribution of dinoflagellates and the fact that some genera are not toxic. In fact, HAS might not be uniformly distributed in water, but organised in spots. Moreover, the molluscs may eat a different HAS amount depending on their percentage on the total amount of algae available (Philips et al., 2011).

In other events, no toxic algae were detected, neither before nor contemporary at $\mathrm{OA}$ accumulation, maybe because the temporality of sampling and the presence of toxic algae did not coincide. In some episodes, OA accumulation over legal limits without algal presence may be explained considering the fact that HAS may cause 
OA accumulation for several weeks after their disappearance in water. For example, in FER 2015, OA accumulation was detected for the first time three weeks after the algal presence, but $\mathrm{OA}$ accumulation was still present after more than six weeks after HAS disappearance (Table 2; Figure 2). In SGL, during 2015 no algae were detected in each episode of OA accumulation and no data about previous HAS were available (since they were collected only concurrently with OA accumulation over the legal limits). But considering dynamics in FER and data in literature (Bazzoni, et al., 2018), we may hypothesise that algae were present even many weeks before OA accumulation.

\section{Conclusions}

This study highlighted a seasonal repeatability of OA accumulation in mussels in some areas of Sardinia during the four years analysed. The timing of the seasonal presence of OA changed likely in relation with the variation of local geomorphology and geographic features, and water temperature. Moreover, the presence of OA above the legal limits in some seasons, could be linked to the interaction between HAS presence/absence with environmental parameters such as salinity of sea water, nutrients and particular sea currents that could influence the production of OA. Despite the fact that HAS are thoroughly studied, their presence is still difficult to predict (and therefore a consequent OA production), because it is determined by a complex set of factors. Further studies are necessary to evaluate these factors in order to better understand the seasonality in the production areas in which it was detected. This would allow to the operators in this field to plan a risk map of the areas where OA accumulation is not random but occurs with seasonal trend.

\section{References}

Anderson DM, Gilbert PM, Burkholder JM, 2002. Harmful algal blooms and eutrophication: nutrient sources, composition, and consequences. Estuaries 25:562-84

Allen JJ, Anderson D, Burford M., Dyhrman S, Flynn K, Gilbert PM, Graneli E, Heil C, Sellner K, Smayda T, Zhou M, 2006. Global Ecology and Oceanography of Harmful Algal Blooms, Harmful Algal Blooms in Eutrophic Systems. GEHOAB Report 410C and SCOR. GEOHAB,
Paris/Baltimore, MD. USA, pp 1-74.

Alves-de-Souza C, Varela D, Contreras C, de La Iglesia P, Fernández P, Hipp B, Lagos N, 2014. Seasonal variability of Dinophysis spp. and Protoceratium reticulatum associated to lipophilic shellfish toxins in a strongly stratified Chilean fjord. Deep-Sea Res Pt II 101:152-62.

Anderson DM, Alpemann TJ., Cembella AD, Collos Y, Masseret E, Montreson M, 2012. The globally distributed genus Alexandrium: multificated roles in marine ecosystems and impacts on human health. Harmful Algae 14:10-35.

Aune T, Espenes A, Aasen JAB, Quilliam MA, Hess P, Larsen S, 2012. Study of possible combined toxic effects of azaspiracid-1 and okadaic acid in mice via the oral route. Toxicon 60:895-906.

Bauder AG, Cembella AD, Quilliam MA, 1996. Dynamics of diarrheic shellfish toxins from the dinoflagellate, Prorocentrum Lima, in the bay scallop, Argopecten irraddians. In: Yasumoto T, Oshima Y, Fukuyo Y, eds. Harmful and Toxic Phytoplankton Blooms IOC/UNESCO, Paris, pp 433-81.

Basti L, Uchida H, Matsushima R, Watanabe N, Suzuki T, Yamatogi T, Nagai S, 2015. Influence of temperature on growth and production of pectenotoxin-2 by a monoclonal culture of Dinophysis caudata. Mar Drugs 13:7124-73.

Bazzoni AM, Mudadu AG, Lorenzoni G, Soro B, Bardino N, Arras I, Sanna G, Vodret B, Bazzardi R, Marongiu, Virgilio S, 2018. Detection of Dinophysis species and associated okadaic acid in farmed shellfish: a twoyear study from the western Mediterranean area. J Vet Res 62:13744.

Boni L, Milandri A, Poletti R, Pompei M, 1993. DSP cases along the coastal of Emila Romagna (Northwestern Adriatic sea). In: Smayda TJ, ed. Toxic Phytoplancton Blooms in the Sea. Elsevier, Amsterdam, pp 475-81.

Chavez FP, Messiè M, Pennington JT, 2011. Marine primary production in relation to climate variability and change. Annu Rev Mar Sci 3:222-60.

Edwards M., Johns DG, Leterme SC, Svendsen E, Richardson AJ, 2006. Regional climate change and harmful algal blooms in the northeast Atlantic. Limnol Oceanogr 51:820-29.

France J, Mozetič P, 2006. Ecological characterization of toxic phytoplankton species (Dinophysis spp., Dinophyceae) in Slovenian mariculture areas (Gulf of Trieste, Adriatic Sea) and the implica- tions for monitoring. Mar Pollut Bull 52:1504-16.

Fu FX, Tatters AO, Hutchins DA, 2012. Global change and the future of harmful algal blooms in the ocean. Mar Ecol Progr Ser 470:207-233.

Hallengraeff GM, 1993. A review of harmful algal blooms and their apparent global increase. Phycologia 32:79-99.

Hallengraeff GM, 2003. Harmful Algal Blooms: a Global Overview, Manual on Harmful Marine Microalgae. UNESCO Publishing, Paris: 25-50.

Hegaret H, Shumway SE, Wilkfors GH, Pate S, Burkholder JM, 2008. Potential transfer of harmful algae through relocation of bivalve molluscs. Mar Ecol Progr Ser 361:169-81.

Heisler J, Gilbert PM., Burkholder JM, Anderson DM, Cochlan W, Dennison WC, Dortch Q, Gobler CJ, Heil CA, Humphries E, Lewitus A, Magnien R, Marshall HG, Sellner K, Stockwell DA, Suddleson M, 2008. Eutrophication and harmful algal blooms: a scientific consensus. Harmful Algae 8:3-13.

Lee JS, Igarashi T, Fraga S, Dahl E, Howgaard P, Yasumoto T, 1989. Determination of diarrhetic shellfish toxins in various dinoflagellate species. J. Appl Phycol 1:147-52.

Moore SK, Trainer VL, Mantua NJ, Parker MS, Laws EA, Backer LC, Fleming LE, 2008. Impact of climate variability and future climate change on harmful algal blooms and human health. Environ Health. doi:10.1186/1476-069X-7-S2S4

Naustvoll LJ, Gustad E, Dahl E, 2013. Monitoring of Dinophysis species and diarrhetic shellfish toxins in Flødevigen Bay, Norway: inter-annual variability over a 25-year time series. Food Addit Contam 29:1605-15.

Nincevic-Gladan Z, Skejic S, Buzancic M, Marovic I, Arapov J, Ujevic I, Bojanic N, Grbec B, Kuspilic G, Vidjak O, 2008. Seasonal variability in Dinophysis spp. abundances and diarrhetic shellfish poisoning outbreaks along the eastern Adriatic coast. Bot Mar 51:449-63.

Padedda BM, Pulina S, Magni P, Sechi N, Lugliè A, 2012. Phytoplankton dynamics in relation to environmental changes in a phytoplankton-dominated Mediterranean lagoon (Cabras Lagoon, Italy). AIOL J 3:147-69.

Pitcher GC, Calder D, 2000. Harmful algal blooms of the southern Benguela Current: a review and appraisal of monitoring from 1989 to 1997 . S Afr J Mar Sci 22:257-71

Philips EJ, Badylak S, Christman M, Wolny 
J, Brame J, Garland J, Hall L, Hart J, Landsberg J. Lasi M, Lockwood J, Paperno R, Scheidt D, Staples A, Steindinger K, 2011. Scales of temporal and spatial variability in the distribution of harmful algae species in Indian River Lagoon, Florida, USA. Harmful Algae 10:277-90.

Pizzarro G, Paz B, Gonzales-Gil S, Franco JM, Roguera B, 2009. Seasonal variability of lipophilic toxins during a Dinophysis acuta bloom in Wester Iberia. Differences between picked cells and plankton concentrates. Harmful Algae 8:926-37.

Roguera B, Velo-Suarez R, Park M, 2012. Harmful Dinophysis species: a review. Harmful Algae 14:87-106.
Roguera R, Riobo P, Rodriguez F, Diaz PA, Pizzarro G, Paz B, Franco JM, Blanco J, 2014. Dinophysis toxins: causative organisms, distribution and fate in shellfish. Mar Drugs 12:394-461.

Tibirica C, Fernandes LF, Mafra Junior LL, 2015. Seasonal and spatial patterns of toxigenic species of Dinophysis and Pseudonitschia in a subtropical Brazilian estuary. Braz J Oceanograr. https://doi.org/10.1590/S1679. 87592015071906301

Utermohl H, 1958. Zur vervollkommung der quantitativen phytoplanktonmethodik. Verh Int Verein Theor Angew Limnol 9:1-39.

Wells ML., Trainer VL, Smayda TJ, Karlson BSO, Trick CG, Kuelda RM,
Ishikawa A, Berbard S, Wulff A, Anderson AM, Cochlan WP, 2015. Harmful algal blooms and climate change: learning from the past and present to forecast the future. Harmful Algae 49:68-83.

Yasumoto T, Oshima Y, Yamaguchi M, 1978. Occurence of a new type of shellfish poisoning in the Tohoku district. Bull Jpn Soc Sci Fish 44:1249-55.

Yasumoto T, Sugawara W, Fukuyo Y, Oguri H, Higarashi T, Fujita N, 1980. Identification of Dinophysis fortii as the causative organism of diarrhetic shellfish poisoning in the Tohoku district. Bull Jpn Soc Sci Fish 46:1405-11. 